\title{
Experimental Organism Malignant Hibernoma
}

National Cancer Institute

\section{Source}

National Cancer Institute. Experimental Organism Malignant Hibernoma. NCI Thesaurus. Code C103394.

A malignant neoplasm arising from the brown adipose tissue in animals, usually in the subcutis and the thoracic cavity. 